\title{
Accuracy of doppler ultrasonography in the evaluation of hemodialysis arteriovenous fistula maturity
}

\section{A acurácia da ultrassonografia com Doppler na avaliação da maturação da fístula arteriovenosa para hemodiálise}

\author{
João Humberto da Fonseca Junior ${ }^{1}$; Guilherme Benjamin Brandão Pitta ${ }^{1}$; Fausto Miranda Júnior ${ }^{2}$
}

\author{
A B S S T R A C T
}

\begin{abstract}
Objective: to determine the accuracy of Doppler ultrasonography (USD) for hemodialysis arteriovenous fistula (AVF) maturity. Methods: we included patients with no prior AVF. Each patient underwent two USD examinations. After initiation of hemodialysis, we followed the patients during the first month of the access use and verified its adequacy to hemodialysis sessions. At statistical analysis we measured specificity, sensitivity, accuracy, ROC curve (Receiver operator characteristic) curve, TG-ROC (Two graph receiver operator characteristic) and logistic regression. Results: we included 76 patients, of which 51 completed the study. They formed two groups, those who have had good adequacy for hemodialysis (45) and those who had not (6). The average flow volume (FV) and the average draining vein diameter (DVD) of each group were, respectively: $940 \mathrm{~mL} / \mathrm{min}(95 \% \mathrm{Cl}: 829-1052)$ and $325 \mathrm{~mL} / \mathrm{min}$ (95\% Cl: $140-510)$; and $0.48 \mathrm{~cm}(95 \% \mathrm{Cl}: 0.45-0.52)$ and $0.33 \mathrm{~cm}$ (95\% Cl: $0.27-0.40)$. The area under the ROC curve of FV and DVD were 0.926 and 0.766 , respectively. Conclusion: the accuracy of the measured volume flow measured at the draining vein to evaluate maturation of hemodialysis arteriovenous fistula was $85 \%$.
\end{abstract}

Key words: Arteriovenous Fistula. Hemodialysis. Ultrasonography, Doppler, Color.

\section{INTRODUCTION}

In Brazil, over 91,000 patients are undergoing dialysis, with $66.9 \%$ within the age group 19-64 years; the two main base diseases are hypertension and diabetes mellitus ${ }^{1}$.

The vascular access for hemodialysis is critical to the proper treatment of patients with kidney failure, since through it patients' blood can be transferred to the dialysis filter and returned to the patient in a continuous process, which usually takes three to four hours, three times a week². The monitoring and surveillance of these approaches provide better patency, reducing the complications inherent to their use $^{3}$.

The maturation of the arteriovenous fistula (AVF) has been studied by Doppler ultrasonography (DUS) and the results were related to the adequacy of hemodialysis sessions. Some studies have addressed this time of vascular access-related AVF, providing quantitative data on maturation of newly created accesses ${ }^{4-7}$.

After installation of the AVF for hemodialysis, the patient may benefit from a quantitative criterion based on DUS to assess the maturity of this access and to allow the first puncture 4 .

Quantitative and easily reproducible criteria for assessing fistula maturity and helping the clinical decision when conducting this access will be extremely useful in daily practice. The objective of this study was to determine DUS accuracy in assessing the maturity of hemodialysis AVF.

\section{METHODS}

We studied patients with arteriovenous fistulas made in the upper limb. We conducted a prospective, diagnostic test cohort study at the Clínica de Nefrologia de Juazeiro, State of Bahia - BA, Brazil. The project was approved by the Ethics in Research Committee of UNCISAL (Universidade Estadual de Ciências da Saúde de Alagoas), Maceió, State of Alagoas - AL (29/05/2006/509). All patients who agreed to participate in the study signed a free and informed consent form. In this work, the prostheses will not be object of study.

Patients were referred by the nephrologist for their first surgical vascular access in the upper limb. Once we defined the best anatomical site for performing the access, the arteriovenous fistula (AVF) was made. We used a technique with a terminolateral anastomosis of the vein with the artery in all patients with 6-0 and 7-0 polypropylene sutures, according to the vessels diameter, with the aid of

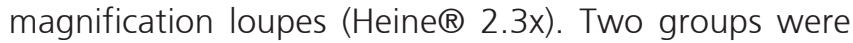

1. Departamento de Cirurgia, UNIFESP - São Paulo - SP - Brasil; 2. Serviço de Cirurgia Vascular do Departamento de Cirurgia, UNIFESP - São Paulo - SP - Brasil. 
formed, those who had good adaptation to hemodialysis and those who had not.

Each patient underwent two DUS exams, the first between the 10th and the 20th postoperative day and the second between the 30th and the 40th. After the second examination, we followed patients clinically as for the result of their hemodialysis sessions for a minimum period of one month after the start of AVF. The main investigator performed the DUS Exams (Figures 1 and 2). We used a Doppler ultrasound device (Hewlett-Packard $₫$, model Image Point) with5-10 MHz variable frequency linear transducer.

The examination followed the evaluation protocol for the upper limb and was held in a room with the patient lying supine with the arm resting on the exam table ${ }^{8}$.

The flow in a AVF draining vein typically has an increased systolic and diastolic velocity with a low resistance biphasic pattern (Figures 1 and 2), in a vessel with very superficial location. Adjustment is necessary regarding the depth, the pulse repetition frequency, the insonation angle, and the Doppler angle, which was set to 60 degrees, as well as the sample volume including the entire vessel lumen so that the spectral curve has the best graphical representation.

Once completed the fistula maturation period, which was 45 days, the patients were clinically examined for the presence of fremitus in the fistula drainage vein and were referred to the hemodialysis as any other patient from the nephrology clinic, using the AVF for hemodialysis sessions.

The adequacy of the AVF for hemodialysis sessions was set when the patient performed at least six hemodialysis sessions with four hours within one month, as prescribed by a nephrologist. Hemodialysis sessions were performed with devices of Baxter $§$ brand, TINA 1200 model.

The accuracy of ultrasound was calculated based on the relationship between the DUS and the results of hemodialysis sessions ${ }^{4}$. With an estimated proportion of the population of $50 \%$, with absolute precision of $15 \%$ and significance level of $5 \%$, we calculated the sample size in 43 patients $^{9}$. The alpha value was $d^{\prime \prime} 0.05 \%$.

We used the programs "R"10 and "SAS"11 for the construction of the TG-ROC (Two Graph - Receiver operator characteristic) curve, the ROC curve (Receiver operator characteristic), the flow volume (FV) and the draining vein diameter (DVD), the area under the ROC curve, the confidence interval and the logistic regression.

\section{RESULTS}

We registered 76 patients, of which 25 did not complete the survey (Figure 3 ). We carried out 46 radiocephalic arteriovenous fistulae (AVF) and five brachiocephalic, in 30 men and 21 women. The performance of two Doppler ultrasound examinations (DUS) during the FAV maturation period allowed us to observe an

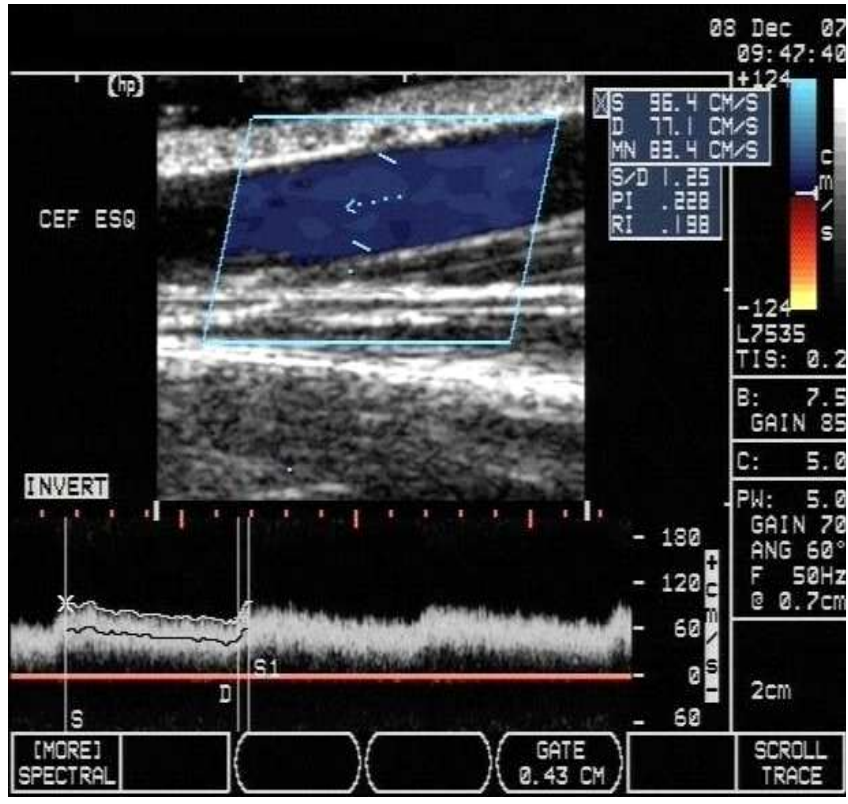

Figure 1 - DUS of draining vein in the middle third of forearm, with the representation of image and spectral Doppler, and automatic measurement of average speed.

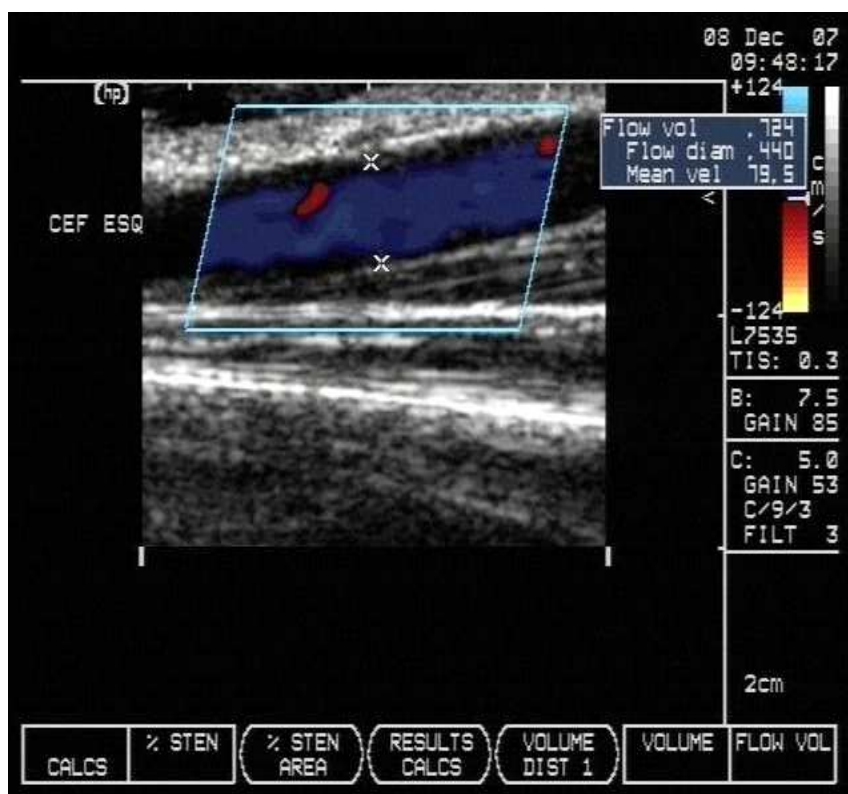

Figure 2 - DUS of draining vein in the middle third of forearm with the representation of the color Doppler image, ending with the manual measure of vessel diameter to calculate the flow volume.

increase in flow volume (FV) and average draining vein diameter (DVD) in $59 \%$ and $65 \%$ of patients, respectively.

The average fistula FV in 45 patients who had a good adaptation to hemodialysis sessions was $940 \mathrm{ml} / \mathrm{min}$ (95\% Cl: 829-1052). The six patients who did adapt to hemodialysis presented an average flow of $325 \mathrm{ml} / \mathrm{min}$ (95\% Cl: 140-510). The average flow adjusted by the nephrologist in the hemodialysis machine was $343 \mathrm{ml} / \mathrm{min}$ (95\% Cl 341-345). 


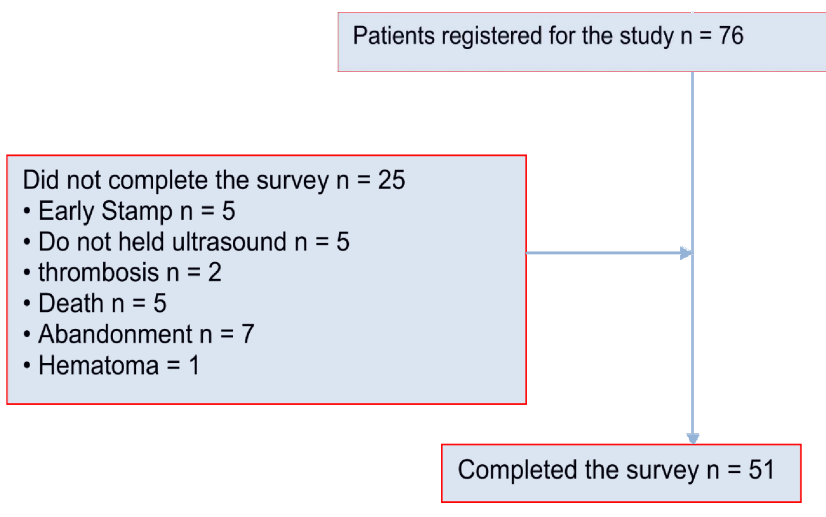

Figure 3 - Deviations in the research.

The average DVD of the 45 patients who had a good adaptation to hemodialysis was $0.48 \mathrm{~cm}(95 \% \mathrm{Cl}$ : $0.45-0.52)$. The six patients who did not meet the adequacy criteria had an average diameter of $0.33 \mathrm{~cm}(95 \% \mathrm{Cl}$ : $0.27-$ 0.40).

The accuracy, sensitivity and specificity of DUS were calculated based on the variation of the cut-off point $(100 \mathrm{ml} / \mathrm{min})$ as for the $\mathrm{FV}$ and on the cutoff point variation $(0.1 \mathrm{~cm})$ as for the DVD, with the three curves simultaneously demonstrating the measures for each cut-off point.

The FV cutoff that best represents DUS accuracy to assess AVF maturity for hemodialysis is located at the point of intersection of the accuracy, sensitivity and specificity curves (Figure 4), ie, between 500 and $600 \mathrm{ml} / \mathrm{min}$. Using logistic regression, we estimated this point at $517 \mathrm{ml} / \mathrm{min}$, which corresponds to an accuracy of $85 \%$.

The DVD cutoff point that best represents DUS accuracy to assess AVF maturity for hemodialysis is located at the point of intersection of the accuracy, sensitivity and specificity curves (Figure 5), ie, between 0.4 and $0.5 \mathrm{~cm}$. Using logistic regression, we estimated this cutoff at 0.45 $\mathrm{cm}$, which corresponds to an accuracy of $66 \%$.

The DVD and FV areas under the ROC curve were, respectively, 0.766 and 0.926 (Figure 6), thereby showing that both have statistical significance, as they are higher than 0.5 , but the FV proved to be the most important parameter when considering the relationship between curves.

\section{DISCUSSION}

We conducted two Doppler ultrasonography (DUS) exams for the monitoring of the arteriovenous fistulas (AVF) maturation process. Results showed an increase in flow volume (FV) and the draining vein diameter (DVD), confirming the recommendation that the maturation process exists and needs to be respected for a better use of the vascular access.

An important contribution of our study is the finding of increased DVD and FV, by $50 \%$ and $52 \%$ of cases, respectively, between the completion of the first DUS exam and the second, suggesting that in half the cases there will be development and expansion of the circulatory system, confirming the need to wait for no less than a 40-day maturity period to start using this access.

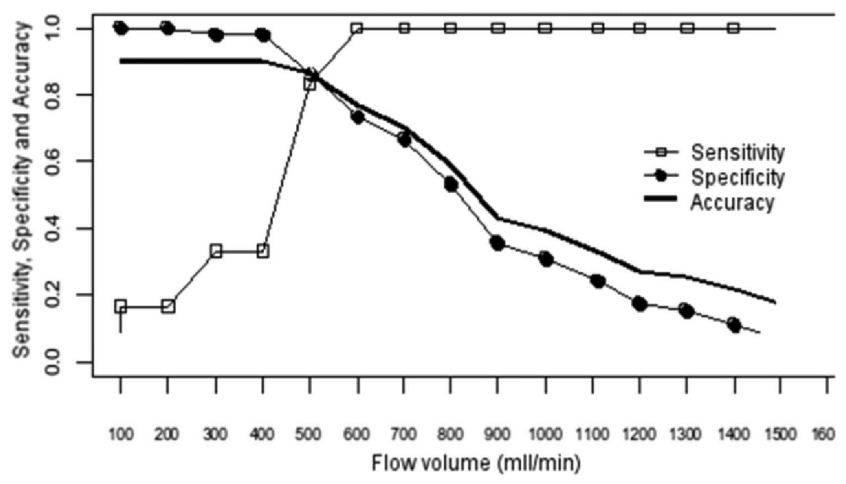

Figure 4 - TG-ROC Curve, sensitivity, specificity and accuracy percentage demonstration (ordinate) of cutoff points for the flow volume (abscissa). The curves intersect between 500 and $600 \mathrm{ml} / \mathrm{min}$.

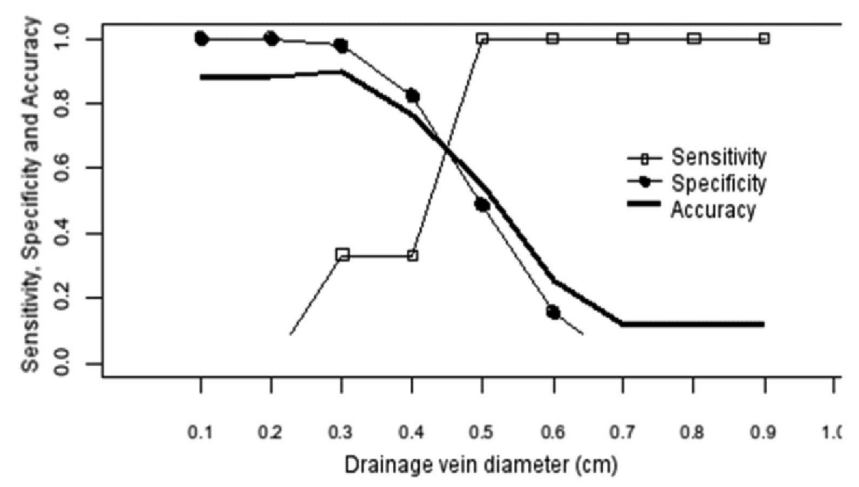

Figure 5 - TG-ROC Curve, sensitivity, specificity and accuracy percentage demonstration (ordinate) of cutoff points parts of the draining vein diameter (abscissa). The curves intersect between 0.4 and $0.5 \mathrm{~cm}$.

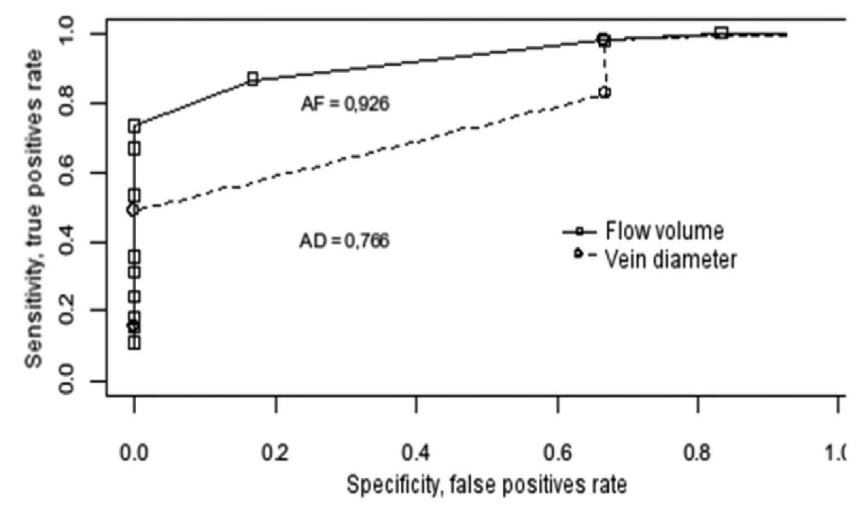

Figure 6 - ROC curve, sensitivity (ordinate), specificity (abscissa), squared $R O C$ curve $=$ flow, circle $R O C$ curve $=$ drainage vein diameter, $A F=R O C$ curve area of the flow volume, $A D=R O C$ curve area of the draining vein diameter. 
Our study found data similar to Toregeani et al. They evaluated the arteriovenous fistula maturation process by serial DUS monitoring as for the progression of the diameter of the draining vein and flow, especially for fistulas on the wrist ${ }^{12}$.

Data from the NKF-K/DOQI ${ }^{13}$, when compared to ours, differ in cutoff points, since the rule of three " 6 " could hardly be applied to our reality, especially when we would have to consider veins with a minimum of $0.6 \mathrm{~cm}$ in diameter to achieve the optimum condition of maturation of said vein. This research found a flow volume and a drainage vein diameter cutoff point where we could suggest the creation of the rule of " 5 ", with $500 \mathrm{ml} / \mathrm{min}$ and $5 \mathrm{~mm}$, respectively, to the adequacy of hemodialysis sessions.

There have been attempts to establish quantitative parameters for AVF maturation ${ }^{4,5,7,13}$. Thus, this research is in accordance with these aspects and coincides with parameters used in different countries, especially concerning the $\mathrm{FV}$ with a cutoff of $500 \mathrm{ml} / \mathrm{min}$ as a minimum suitable AVF value to perform hemodialysis sessions.

Robbin et al. did not calculate the area under the ROC curve ${ }^{4}$, which undoubtedly is a failure in their article, since this parameter is of utmost importance to validate the diagnostic test used ${ }^{14}$. According to Zhu et al., the area under the ROC curve can undergo stratification so as to indicate the diagnostic test's accuracy or overall precision, where close to 0.5 the diagnostic testing approaches randomness, and the ROC curve classified as insufficient, and when it approaches 1.0, it scores as excellent ${ }^{14}$.

According to Martinez et al., the TG-ROC curve proposes an alternative way of demonstrating the performance of a diagnostic tes $\mathrm{t}^{15}$, with important additional information, the choice of the optimal cutoff point. In this same model it is possible to include the diagnostic test's accuracy curve. In our research, we found that, as for FV, the crossing point of sensitivity, specificity and accuracy was a point between 500 and $600 \mathrm{ml} / \mathrm{min}$. This point best represented AVF maturation in 39/45 patients, with an accuracy of $86.3 \%(95 \% \mathrm{Cl}: 73-94)$ (Figure 4), and is in line with the literature ${ }^{3,5}$. The DVD TG-ROC, which shows the three curves simultaneously, revealed a crossing point between 4 and $5 \mathrm{~mm}$, which is the cutoff point that best represented AVF maturation in 37/45 patients, with an accuracy of $66 \%$ (95\% Cl: 68-90) (Figure 5).

Biuckians et al. ${ }^{6}$ make a reflection on the NKF$\mathrm{K} / \mathrm{DOQ}$ recommendations ${ }^{13}$, so that the number of fistulas as the first patient access increases. However, at the end of the segment period, they found that only $48 \%$ of arteriovenous fistulas were being used, and $11 \%$ reached the maturation period without some kind of intervention. These data differ from our practice, since in our study $86 \%$ of patients achieved a good adaptation to hemodialysis in an average period of 45 days.

The problem of AVF maturation for hemodialysis has at least two facets with impact on clinical practice: the first would be the judgment about time of maturation, and the second is how this judgment would be best accomplished. This research contributed precisely with these two aspects, particularly with the form of judgment, because in our country, the average period of maturation is already well established (one to two months). But as for the form of judgment, where until recently the clinical examination was the only alternative, the DUS provides information that can help in the decision to consider that access mature.

DUS has contributed in this research, with the measure of FV and the DVD, establishing parameters that, once achieved, allow a more detailed access evaluation, thereby facilitating the doctor who is knowledgeable of these parameters to review the DUS report and, associated with a good clinical examination, conclude about the access evolution and about the maturation period. As a practical contribution, we can suggest that every DUS exam related to AVF assessment has the FV information measured in the draining vein. The FV should be quickly and easily available in DUS devices, reducing the bureaucracy of access to this information, which limits the execution of this test for many examiners.

The understanding of the AVF maturation process is constantly evolving. Being an affordable method, DUS allows the study of this process with minimal invasiveness and with parameters which can be added to better reflect AVF adequacy to hemodialysis.

Clinical studies have linked the accurate physical examination in association with the DUS as a way to substantiate the best clinical decision to be made in the AVF maturation period ${ }^{4,16}$. These studies, as well as the guidelines of the NKF-K/DOQI ${ }^{14}$, allow to suggest that the investigation of the AVF maturation period can be completely unveiled, however, new study parameters provided by the DUS continue in development, leaving a door open for scientific research continue to work.

This study suggests a new approach to the evaluation of the AVF maturation process and correlates the DUS with the adequacy to the hemodialysis sessions. Deepening the study of this correlation is a new path that will continue bringing relevant information to the AVF management.

In conclusion, the accuracy of the flow volume measured in the draining vein to assess the fistula maturity for hemodialysis was $85 \%$, which is the best available parameter alone. The combination of parameters can further improve these figures; there is need to deepen and develop new studies for the improvement of the technique. 
Objetivo: testar a acurácia da ultrassonografia com Doppler (USD) na avaliação da maturação do acesso vascular para hemodiálise. Métodos: foram incluídos pacientes que não haviam feito uma fistula arteriovenosa (FAV) anteriormente. Cada paciente foi submetido a dois exames de USD. Após o início da hemodiálise, foram acompanhados durante o primeiro mês utilizando o acesso e verificando sua adequação às sessões de hemodiálise. Foram aferidas: especificidade, sensibilidade, acurácia, curva ROC (Receiver operator characteristic), curva TG-ROC (Two graph - receiver operator characteristic) e regressão logística. Resultados: foram incluídos na pesquisa 76 pacientes, 51 concluíram o estudo. O volume de fluxo (VF) médio e o diâmetro médio da veia de drenagem (DVD) foram, respectivamente, para cada grupo: $940 \mathrm{ml} / \mathrm{min}$ (IC95\%: 829-1052 ml/min); $325 \mathrm{ml} / \mathrm{min}$ (IC95\%: $140-510 \mathrm{ml} / \mathrm{min}$ ); e 0,48cm (IC95\%: 0,45-0,52 cm); 0,33cm (IC95\%: 0,27-0,40 cm). A área sob a curva ROC do VF e do DVD foram, respectivamente, 0,926 e 0,766. Conclusão: A acurácia da medida de volume de fluxo aferido na veia de drenagem para avaliar a maturação da fistula de hemodiálise foi $85 \%$, o melhor parâmetro disponível isoladamente.

Descritores: Fístula arteriovenosa. Hemodiálise. Ultrassonografia Doppler em Cores

\section{REFERENCES}

1. Sociedade Brasileira de Nefrologia. Censo da Sociedade Brasileira de Nefrologia 2011 [online]. 2013 [capturado 10 de fev. 2011]. Disponível em: http://www.sbn.org.br/pdf/censo_2011_publico.pdf.

2. Lugon JR, Matos JPS, Warrak EA. Hemodiálise. In: Riella MC. Princípios de Nefrologia e Distúrbios Hidroeletrolíticos. 4a ed. Rio de Janeiro: Guanabara Koogan; 2003. p. 869-907.

3. III. NKF-K/DOQI Clinical Practice Guidelines for Vascular Access: update 2000. Am J Kidney Dis. 2001;37(1 Suppl 1):S137-81.

4. Robbin ML, Chamberlain NE, Lockhart ME, Gallichio MH, Young CJ, Deierhoi MH, et al. Hemodialysis arteriovenous fistula maturity: US evaluation. Radiology. 2002;225(1):59-64.

5. Basile C, Casucci F, Lomonte C. Timing of first cannulation of arteriovenous fistula: time matters, but there is also something else. Nephrol Dial Transplant. 2005;20(7):1519-20.

6. Biuckians A, Scott EC, Meier GH, Panneton JM, Glickman MH. The natural history of autologous fistulas as first-time dialysis access in the KDOQI era. J Vasc Surg. 2008;47(2):415-21; discussion 4201.

7. Brunori G, Ravani P, Mandolfo S, Imbasciati E, Malberti F, Cancarini G. Fistula maturation: doesn't time matter at all? Nephrol Dial Transplant. 2005;20(4):684-7.

8. Robbin ML, Lockhart ME. Avaliação ultra-sonográfica antes e depois de acesso para hemodiálise. In: Zwiebel WJ, Pellerito JS. Introdução à Ultra-Sonografia Vascular. $5^{\text {a }}$ ed. Rio de Janeiro: Elsevier; 2005. p. 325-40.

9. Lwanga SK. Sample size determination in health studies: a practical manual. Geneva: World Health Organization; 1991.
10. R Development Core Team (2011). R: A language and environment for statistical computing. R Foundation for Statistical Computing [online]. Vienna, Austria; 2011. [capturado 10 fev 2011]. Disponível em: http://www.R-project.org/

11. The SAS Learning Edition 4.1; Copyright (c) 2002-2003 by SAS Institute Inc., Cary, NC, USA.SAS (r) 9.1 (TS1M3) [online]. 2013 [capturado 10 fev 2011]. Disponível em: http://www.sas.com/

12. Toregeani JF, Kimura CJ, Rocha AST, Volpiani GG, Bortoncello A, Shirasu K, et al. Avaliação da maturação das fistulas arteriovenosas para hemodiálise pelo eco-Doppler colorido. J vasc bras. 2008:7(3):203-13.

13. Vascular Access Work Group. Clinical practice guidelines for vascular access. Am J Kidney Dis. 2006;48 Suppl1:S248-73.

14. Zhu W, Zeng N, Wang N. Sensitivity, specificity, accuracy, associated confidence interval and ROC analysis with practical SAS Implementations. Baltimore: Health Careand Life Sciences; 2010.

15. Martinez EZ, Louzada Neto F, Pereira BB. A curva ROC para testes diagnósticos. Cad saúde colet. 2003;11(1):7-31.

16. Campos RP, Chula DC, Riella MC, Nascimento MM. O exame físico como método de detecção de estenose da fístula arteriovenosa. J Bras Nefrol. 2007;29(2):64-70.

Received on 10/07/2014

Accepted for publication 22/08/2014

Conflict of interest: none.

Source of funding: none.

Address for correspondence:

Fausto Miranda Júnior

E-mail: fmiranda@apm.org.br 